\title{
ARTICLES
}

\section{The Right to Have Rights as the Right to Asylum*}

\author{
Nanda Oudejans
}

In The Origins of Totalitarianism Hannah Arendt offers a profound reflection on the refugee question. The hallmark of Arendt's analysis has been believed to be her emphasis on the refugee's loss of political status, ${ }^{1}$ captured by the core phrase of the 'fundamental deprivation of a place in the world which makes opinions significant and actions effective.' ${ }^{2}$ This allegedly features what Arendt famously coined as the right to have rights. Against the backdrop of the deprivation of 'the right to action' and 'the right to opinion' ${ }^{3}$ it would seem as if the historic-political context of refugee displacement occasioned the right to have rights but that, ultimately, exclusion from politics provides the conceptual background thereto. Whereas Arendt explicitly targeted the dire predicament of refugees, contemporary readings of her work have tailored the right to have rights to various inclusion and exclusion dilemmas in the context of human equality. On the assumption that the right to have rights contains the nucleus of Arendt's later reflections on the meaning of politics, it is believed to hinge on the always unstable public/ private divide that in many respects is central to her work. As a consequence, the right to have rights not only - or even no longer - covers the refugee's plight but equally attaches to those subjects who are tormented in their speaking capacity and are pushed back to the margins of society where the light of the public realm simply does not reach. Cast as the lens through which different forms of life and marginalized identities might gain public visibility, the right to have rights is appropriated by a contestatory politics that seeks to vindicate fundamental rights for - in the words of Bonnie Honig - 'minorities, the stateless, the powerless and the hapless'; ${ }^{4}$ principled on access to the public space it became a right to politics; ${ }^{5}$ acting out a rival 'We' this right is rallied to the call of what Benhabib

* The author is grateful for comments on earlier versions of this article made by Juan AmayaCastro, Marieke Borren, Bart van Klink, Roland Pierik, Thomas Spijkerboer, Marc de Wilde, and the NJLP's two anonymous referees.

1 Cf. Monika Krause, 'Undocumented Migrants. An Arendtian Perspective,' European Journal of Political Theory 7 (2008): 335.

2 Hannah Arendt, The Origins of Totalitarianism, new edition (San Diego/New York/London: Harcourt, 1968), 296.

3 Ibid.

4 Bonnie Honig, Emergency Politics. Paradox, Law, Democracy (Princeton: Princeton University Press, 2009), 117.

5 Cf. Andrew Schaap, 'Enacting the Right to Have Rights. Jacques Rancière's Critique of Hannah Arendt,' European Journal of Political Theory 10 (2011): 33. 
coins the 'ongoing processes of transformation and reflexive experimentation with collective identity.' ${ }^{\prime}$

The projection into different contexts of exclusion successfully taps the rich potential of meaning the right to have rights harbours, and has certainly contributed to the understanding of the concept. This should not hide from view, however, that the dilemma the refugee faces upon fleeing crucially differs from the various forms of exclusion as experienced by those within communities whose fundamental rights are half-heartedly protected. The right to have rights, it will be argued, has brought awareness to this crucial difference. This article therefore resituates the right to have rights within the circumscribed context of refugee displacement, arguing that it is wholly reductive to understand the refugee's dilemma in terms of the exclusion from politics. It sets out to demonstrate that the exclusive focus on the public/private divide that predominates in contemporary readings of Arendt, and the subsequent understanding of the right to have rights as a response to exclusion from politics and public invisibility distorts our understanding of the refugee problem and, in a sense, fails the refugee. As the right to have rights is relative to the loss of state protection, it will be argued that it captures the dilemma the refugee faces upon fleeing and for which he seeks international redress as well as the dilemma he faces in claiming such redress. What we gain by limiting the right to have rights to the refugee's plight, is an alternative conceptual framework wherein to articulate the refugee dilemma that, moreover, elucidates the refugee's claim to asylum.

The argument proceeds from the refugee's exclusion from politics yet takes issue with the rash turn to politics that invites refugees to 'go public' ${ }^{\text {'7 }}$ in order to remedy this political aberration. Instead it will be argued that the refugee's loss of political status rather exposes his powerlessness with respect to his own inclusion, and therefore manifests the deep and unavoidable asymmetry between him and the receiving state.

Secondly, this implies that it is wholly reductive to limit the refugee's plight to the loss of politics and align it with exclusion from the public realm. Rather than focusing on the public/private divide, I will propose another direction of thought, taking my lead from Arendt's sparse but important remarks on law's boundedness to place. ${ }^{8}$ Law's spatiality casts new light on the deprivation of a place in the world. The refugee is not only without a world in the thorough political sense in which Arendt understands the notion of a world, also he is nowhere in the world in a legal sense.

6 Seyla Benhabib, The Rights of Others. Aliens, Residents and Citizens (Cambridge: Cambridge University Press, 2004), 64.

7 Cristina Beltrán, 'Going Public. Hannah Arendt, Immigrant Action, and the Space of Appearance,' Political Theory 37 (1998): 3.

8 In an article from 2004 Hans Lindahl unearthed Arendt's recovery of the spatiality of law. See Hans Lindahl, 'Finding Place for Freedom, Security and Justice. The European Union's Claim to Territorial Unity,' European Law Review 29 (3) (2004): 462-3. 
Thirdly, this helps us to gain better understanding of Arendt's well-aimed but often poorly understood or simply ignored critique of the sharp-edged distinction between refugees and stateless persons which, as will be argued, is as important as her critique of human rights. Reading Arendt in the context of the legal and political debate of her own time, the right to have rights appears as the lookingglass through which both the refugee and the stateless persons share in the same dilemma: having lost a place of their own, where do they have the right to live?

Finally, this marks the ongoing relevance of Arendt's analysis to present debates on refugee protection. It certainly is tempting to point out disturbing parallels ${ }^{9}$ between Arendt's time and the glaring failure to protect refugees today. ${ }^{10}$ Yet, it is also useful to bring out the defiant potential of the right to have rights to illuminate what, exactly, the refugee is claiming in claiming asylum. As GrahlMadsen, a pioneer in refugee law, has pointed out 'the term "asylum" has no clear agreed meaning. '11 The disarray with respect to 'asylum' became particularly manifest with the Charter of Fundamental Rights of the European Union (2000) which includes in Article 18 a right to asylum. Due to the 'vagueness of the institution'12 legal scholars have described Article 18 as 'linguistically vague. ${ }^{13}$ Although seemingly expansive, legal scholars argue that Article 18 does not refer to anything other than a procedural right to seek asylum. ${ }^{14}$ Paradoxically, then, we do not know what, exactly, the refugee is claiming when claiming asylum. This article argues that the right to have rights clears the intellectual fog surrounding the concept of asylum. As the right to have rights targets the refugee "between flight and arrival' so as to get a hold on the dilemma he faces upon fleeing, the term 'refugee' shall not, for the purposes of this article, refer to a person recognized by a state to be in need of international protection, but is used as such in a conceptual manner.

\section{Abstract Life and Private Life}

This section briefly sketches the two distinguishing features of the refugee's plight as outlined by Arendt. It then tries to reconstruct the detachment of the right to have rights from the refugee's plight and the subsequent dissemination over various contexts of exclusions.

9 Cf. Marieke Borren, 'Towards an Arendtian Politics of In/Visibility: On Stateless Refugees and Undocumented Aliens,' Ethical Perspectives 15 (2008): 225.

10 As one legal scholar voices with respect to the development of a Common European Asylum System: 'It is difficult not to be shocked by the current situation' (Elspeth Guild, 'The Europeanisation of Europe's Asylum Policy,' International Journal of Refugee Law, 18 (2006): 631).

11 Cf. Alte Grahl-Madsen, Territorial Asylum (Stockholm/London: Almqvist \& Wiksell International, 1980), 50 .

12 Guy Goodwin-Gill and Jane McAdam, The Refugee in International Law (Oxford: Oxford University Press, 2007), 358.

13 Gregor Noll, 'Seeking Asylum at Embassies. A Right to Entry under International Law?,' International Journal of Refugee Law 17 (2005): 548.

14 Goodwin Gill \& Mc Adam, The Refugee in International Law, 367-8. 
As is well-known, the right to have rights is Arendt's response to the failure of human rights to protect refugees who were scattered around Europe as a consequence of the two wars that had ravaged the continent. In fact, her critique gauged the protection gap in international law which, already at the beginning of the twentieth century, constituted a matter of great concern within the international community. ${ }^{15}$ The gap resulted from the fact that the individual when abroad did not enjoy protection in a foreign territory in virtue of his status as a rights-bearing subject but on account of his status as a national of a foreign friendly nation. ${ }^{16}$ Since the refugee had lost the protection of his home government that would give him its backing in the international arena the refugee could not lay claim to international protection. Hence Arendt was able to argue that the 'rights of man (...) proved to be unenforceable (...) whenever people appeared who were no longer citizens of any state. ${ }^{\prime 17}$ Having lost the protection of a home government while being unable to invoke protection under international law, refugees suffered from the 'abstract nakedness of being human and nothing but human. ${ }^{18}$

The loss of a legal status also carries a deep political dimension. Drawing on the Roman understanding of law as lex which, according to Arendt means 'lasting tie,' she emphasizes in The Promise of Politics that law is what binds people together, not by force or diktat but through the mutual process of speaking and acting with each other. ${ }^{19}$ Without a law that protects them, refugees are also thwarted in their capacities to speak and act together with others. They are not only deprived of the rights of citizens, Arendt argues, but also from what she holds to be truly 'human rights,' namely the rights to action and to speech. Rendered speechless and obstructed in the capacity to build and change a common world together with others, refugees are 'without a world' ${ }^{20}$ in the thorough political sense in which Arendt understands the notion of a world. A world is what thrusts itself inbetween ${ }^{21}$ men whenever they come and speak together. ${ }^{22}$ It is what they have in common and what they share by exchanging their opinions and views that are always unique. The intricate interplay between commonness and uniqueness, and between equality and difference makes up a world and constitutes what Arendt calls the political fact of human plurality. ${ }^{23}$ In her view, the most fundamental dimension of the world is therefore the public realm 'where I appear to others as

The concern was first expressed by the International Red Cross. Cf. Memorandum From the Comité de la Croix-Rouge at Geneva to the Council of the League of Nations, League of Nations Official Journal March-April (1921): 228.

16 Cf. Haro van Panhuys, The Rôle of Nationality in International Law (Leiden: Sijthoff's Uitgeversmaatschappij, 1959), 44.

17 Arendt, The Origins of Totalitarianism, 293.

18 Ibid., 297.

19 Cf. Hannah Arendt, The Promise of Politics (Chicago: Chicago University Press, 2005), 179.

20 Ibid., 196.

21 Hannah Arendt, Men in Dark Times (London: Jonathan Cape, 1970), 4.

22 Cf. Arendt, The Promise of Politics, 106.

23 Ibid., 93. 
others appear to me.'24 Only in the public realm where various unique viewpoints illuminate the world - making it, indeed, a human world ${ }^{25}$ - can freedom truly blossom ${ }^{26}$ and do we attain our 'full reality as men.'27 'A life without speech and action,' Arendt says in The Human Condition, 'is literally dead to the world; it has ceased to be human life as it is no longer lived among men.'28

The right to have rights signals the situation of complete rightlessness as the refugee is without a status that protects him as well as his exclusion from the world of public life. As refugees lived 'outside of politics' and 'without belonging to any polity,' ${ }^{29}$ they constituted, as the legal scholar Weis observed, an 'absurdity' in the human world as their lives are severed from any specific human relations that are lived and acted upon in 'a certain community of interests, habits and thoughts.'30 Against the backdrop of this absurdity Arendt muses on the right to have rights as the need 'to live in a framework where one is judged by one's actions and opinions' and that qualifies as 'a right to belong to some kind of organized community.' 31

Compounding the meaning of the right to have rights out of the threefold of action, speech and judgment seemingly weaves an unequivocal link between Arendt's reflections on the refugee question and her inquiries into the meaning of politics. As Andrew Schaap puts it: 'Arendt's analysis of the perplexities of the rights of man thus presupposes the conception of the political that she articulates more fully in The Human Condition. ${ }^{32}$ Indeed, the distinctions Arendt draws between the public and the private sphere, between the good life of the citizen and mere existence as well as the intertwinement she exposes between agency and rights, are believed to hold the philosophical keys to the (practical) meaning of the right to have rights. The two parts of the conjunction that refugees are deprived of a place in the world and are suffering from the abstract nakedness of being human has been believed to be conceptually linked to the exclusion from the public realm and the ensuing condemnation to the silence and darkness of a private existence. ${ }^{33}$ Rancière puts the conceptual linkage on the spot when he argues that the

'equation itself was made possible by Arendt's view of the political sphere as a specific sphere, separated from the realm of necessity. Abstract life meant

24 Hannah Arendt, The Human Condition: A Study on the Central Dilemma's Facing Modern Man (New York: Doubleday Anchor Book, 1959), 177.

25 Cf. Arendt, Men in Dark Times, 30-31.

26 Cf. Arendt, The Promise of Politics, 169-70.

27 Ibid., 21.

28 Arendt, The Human Condition, 176.

29 Arendt, The Promise of Politics, 6.

30 Paul Weis, The Problem of Statelessness (London: Reports of the World Jewish Congress, British Section, 1944), 21.

31 Arendt, The Origins of Totalitarianism, 296-7.

32 Schaap, 'Enacting the Right to Have Rights,' 26.

33 Beltrán, 'Going Public,' 5. 
"deprived life". It meant "private life", a life entrapped in its idiocy, as opposed to the public life of public action, speech and appearance. 34

To be sure, Rancière reproaches Arendt for making an ontological distinction out of the public/private divide. Yet the equation he explicates bears out the predominant view that this divide is the very locus of the right to have rights. Benhabib, for example, rejoices at the right to have rights as the lens through which tensions between the particularity of democracy and the universality of human rights can be mitigated. Through this lens we are able, for example, to evaluate the political significance of the refusal of Muslim women to unveil themselves in their classrooms and understand that their headwear represent what we both believe to be universal, i.e. our female dignity. By acting out a rival 'We' they force, Benhabib argues, what is taken 'as a private symbol - an individual item of clothing - into the shared public sphere, thus challenging the boundaries between the public and the private. 35

The widely held assumption that the right to have rights hinges on the public/ private divide effectuated the passage from the refugee's plight he suffers outside his own country, to the exclusions, injustices and inequalities which minorities and the oppressed are experiencing within given communities. However, as the next section argues, it is way too quick to assume that the terms in which Arendt stated (part of) the problem (loss of political status), are the very same terms in which a solution is to be found: political action and inclusion or, as Monkia Krause argues, the creation of spaces of public freedom ${ }^{36}$ in which 'the stateless' miraculously appear as 'privileged political actors. ${ }^{37}$ As the refugee's freedom of opinion does not in the least change his rightlessness, as Arendt says, ${ }^{38}$ his exclusion from the world of public life must be taken to reflect a more intricate dilemma, as will be argued below.

\section{The Asymmetry Between Refugees and Democracies}

It is relatively easy to see why locating the right to have rights squarely into politics results in an untenable position, at least with respect to refugees. To stick with the example of the defiant Muslim women whose actions and opinions Benhabib evaluates: however unsatisfactory their position may be as they are obstructed in exercising their religion, they are nevertheless embedded within a particular community, albeit one that does not, they claim, look into their interests. They participate in the educational system and are even already full members in the legal sense. They claim their rights. Not the right to have rights. This is (2004), 298.

35 Benhabib, The Rights of Others, 187.

36 Cf. Krause, 'Undocumented Migrants,' 343.

37 Ibid., 337.

38 Cf. Arendt, The Origins of Totalitarianism, 296. 
no less true for the women, dissidents and citizens of repressive regimes to whom Rancière resorts and who, according to him, can make a public appearance so as to demand the rights the constitution denied to them. Combatting exclusions, giving voice to what is rendered politically irrelevant and engaging in what Rancière calls a 'dispute about (...) the frame in which we see something as giving', by 'putting two worlds in one and the same world'39 typically takes place, as Arendt would say, 'within given communities. ${ }^{40}$ But refugees reflect the problem of people who 'no longer belong to any community whatsoever. ${ }^{\text {'1 }}$ The refugee is neither already fully inside the polity, which is precisely why he seeks asylum, nor can he be properly located outside - i.e., in a different community, a foreign state - as he cannot be diverted back to wherever he came from since he fears for his life and freedom. Neither inside nor outside, the refugee is far removed from a position to quarrel with the members of the polity about the frame in which they see something as given or by repositing the universal by claiming that headscarves symbolize dignity.

Arendt made an important observation in this respect. Refugees, she notes, 'never banded together, as the minorities had done temporarily, to defend common interests. ${ }^{42}$ The observation is not merely empirical but portends a more basic point. The refugee who flees his own country not only forfeits state protection but 'also he loses the only space in which he can be free' as 'he loses his society of equals. ${ }^{43}$ Having lost his community of equals, the refugee - even if he comes in large numbers - is precisely the one who, according to the desperate phrase of Jean Améry, can no longer say 'We.' ${ }^{\text {'4 }}$ No longer among his consociates who are equal as 'all have the same claim to political activity, ${ }^{45}$ the refugee is unable to understand and represent himself as belonging to a We that has the potential to wrest another way of living out of a people's current existence, as settled immigrants might do. The refugee as refugee does not bring with him the possibility of another We but instead reminds us of the possibility of the absence of a We. Indeed, if refugees are deprived of place in the world, they are withheld from what Edward Casey calls the 'power of place' which 'determines not only where I am (...) but how I am together with others (...) and even who we shall become together.' 46

This sets the stage for the powerlessness which the refugee experiences upon arrival. How We are together, Arendt intimates in On Revolution, is manifested by 'reciprocity and commonness,' by 'mutual agreements and promises,' which gives

40 Arendt, The Origins of Totalitarianism, 395.

41 Ibid., 295.

42 Ibid., 282.

43 Arendt, The Promise of Politics, 119.

44 Jean Améry, Jenseits von Schuld und Sühne (Munich: Deutscher Taschenbuch Verlach, 1970), 58.

45 Arendt, The Promise of Politics, 118.

46 Edward Casey, Getting Back into Place. Toward a Renewed Understanding of Place-World (Bloomington: Indiana University Press, 1993), 23. 
legitimacy to the power to determine who we shall become together. ${ }^{47}$ Indeed, if Arendt holds action and speech to be the true rights, not of man but of men, she does so because those capacities give the members of the group the legitimate power to determine themselves and mutually grant themselves equal rights. Arendt passionately plays the intertwinement of agency, power and rights against human rights. The rights we have, she argues, are not given to us by birth but are the outcome of the joint action between the members of the polity: 'We are not borne equal; we become equal as members of a group on the strength of our decision to guarantee ourselves mutually equal rights. ${ }^{48}$

Hence the dilemma: if the members mutually grant themselves equal rights in virtue of which they determine and unite themselves as a people, ${ }^{49}$ how, then, is the refugee, who is not a member, to claim a right to have rights? Indeed, how is he to claim this right while he is excluded from the rights that give the members of the polity an equal claim to political activity that sets the process of rights-production in motion and keeps it going ? $^{50}$ The right of admission, Arendt argues, therefore equals freedom itself and 'determines a man's life no less than riches and health. ${ }^{51}$ Yet the fundamental problem at issue here is that there is no We between the refugee and receiving polity that binds them together in a relationship of political reciprocity. Put differently, refugees and democracies cannot jointly decide on the refugee's admission. As the very decision on his inclusion or exclusion is always taken from within the polity, the refugee is virtually powerless with respect to his own inclusion.

Of course, the members of the polity might take a sincere inspiration from a moral universalism that supposedly binds them and refugees together in a common humanity and inspires them to act as human beings simpliciter. ${ }^{52}$ Yet, even if this would significantly benefit refugees, there is no getting round that a moral openness to refugees still is the polity's decision and that, ultimately, the polity being addressed decides to grant refugees leave to entry and/or remain. ${ }^{53}$ In a similar vein it is simply false to assume, as legal scholars are prone to do, that refugee protection constitutes a humanitarian exception to the sovereign right of states to select and exclude non-nationals at their borders. This is not to say that international legal obligations are irrelevant. Of course, if a person presents himself at the borders of a territory and claims asylum, that state is obliged to grant protection in accordance with international refugee and human rights law. However, in order to grant protection, a decision has to be made regarding which indi-

Hannah Arendt, On Revolution (New York: The Viking Press, 1963), 181-2.

Arendt, The Origins of Totalitarianism, 301.

Cf. Arendt, The Promise of Politics, 170.

The difficulty involved has been well put by Frank Michelman, 'Parsing a Right to have Rights,' Constellations. An International Journal of Critical and Democratic Theory 3 (1996): 206.

Arendt, The Promise of Politics, 170.

Benhabib makes a suggestion to that end. Cf. Benhabib, The Rights of Others, 14-15.

Hans Lindahl also argues that replacing political reciprocity for a moral reciprocity is of no avail with respect to immigrant rights. Cf. Hans Lindahl, 'In Between. Immigration, Distributive Justice and Political Dialogue,' Contemporary Political Theory 8 (4) (2009): 442. 
viduals come within the ambit of international protection and those who do not. This is a decision of the state, not of the refugee who has little, if any, influence on the state's decision. ${ }^{54}$ Reflecting the inevitable asymmetry between refugees and receiving states, the right to have rights makes us realise that politics is inept, reliance on moral universalism dangerously naive and a focus on law inconclusive.

Moreover, the asymmetry also deeply affects the polity being addressed. Indeed, the right to have rights throws us, as members of democratic polities, back upon ourselves, taking us back all the way down to the origin, to the beginning of our existence as a people. It would seem that if with respect to the inclusion and exclusion of outsiders political reciprocity founders, this also raises fundamental questions as to the people's self-inclusion and self-foundation. ${ }^{55}$ Consider in this respect again Arendt's argument that we become equal as members of a group by mutually guaranteeing ourselves equal rights. In On Revolution Arendt, as said before, asserts that joint action and mutual agreements give the people the power to determine and rule itself. In her view, joint action secures, so to speak, the origin or foundation of the people. But, contra Arendt, the snag is, of course, that reciprocity founders with respect to the very first question of democracy, namely the question who is to be involved in the set of individuals among whom reciprocity reigns, and which man is to count as equal to other men. The question who holds standing as a member and has a right to participation always comes too late since the process of joint action among the members has always already begun. Hence the question who belongs to the people - to be asked and answered by the very same people - already takes the existence of the people for granted. Indeed, what is at stake in the above cited passage from The Origins are the rights the members mutually grant themselves while their status as member of the group is taken for granted. Arendt resorts to the 'strength of our decision', but the point of the matter is that this can never be our decision unless in retrospect. The very first question of democracy, who belongs and who does not, seems therefore, to draw upon a givenness rather than on reciprocity. As joint action and mutual agreements take the existence of the people for granted, the people's selfinclusion escapes the initiating power of speech and action, and therefore also point to what Arendt, somewhat hesitantly, called the 'limits of human activity.' So when Arendt argues that the refugee challenges the assumption of our political life, namely that 'we can produce equality through organization, ${ }^{\text {'5 }}$ she does not surrender to the supposed inevitability of a politics of exclusion. Instead, she tacitly points out the a-democratic and a-political origin of a people that owes its existence to a givenness and a decision that it can never fully make its own. The

54 Legal and linguistic scholars, who conducted research on how the refugee's credibility is constructed, have demonstrated that the asymmetry takes hold of the asylum procedure. See Thomas Spijkerboer, Gender and Refugee Status (Nijmegen: Gerard Noodt Instituut, 1999); Jan Blommaert, 'Language, Asylum and the National Order,' Current Anthropology 50 (2009): 415-44.

55 On the self-inclusion of the people, see Bert van Roermund, 'The Law and We,' Ethical Perspectives 13 (2006): 525-33.

56 Arendt, The Origins of Totalitarianism, 301. 
refugee, Arendt says, 'breaks into the political scene as the alien which (...) reminds us of the limitations of human activity - which are identical with the limitations of human equality. 57

What gives the people its power, i.e. joint action, mutual agreements, promises and reciprocity at the same time renders the people powerless with respect to the question who makes up the people. The lack of political reciprocity between refugees and democracies is a late echo of the lack of reciprocity at the beginning of a people's existence. The right to have rights does not appear, therefore, only at the boundaries that separate the public from the private. It first and foremost appears at the boundaries of a polity that separate an inside from an outside and that are never wholly within the (legitimate) power of a people. The right to have rights radically calls into question the power of a people to determine itself, and, in the wake of that, challenges the concomitant claimed right to select and exclude outsiders in its own interest.

The right to have rights thus brings awareness to the dilemma democracies and refugees face in facing each other. ${ }^{58}$ As will be argued below, it is therefore also wholly reductive to interpret this right as a response to exclusion from the world of public life.

\section{$3 \quad$ Natality and Taking up Place}

This section aims to bring out the full weight of the deprivation of a place in the world, arguing that it should be taken in the strong sense of the loss of own place. The argument carries the dominant idea that the refugee is 'denied the fundamental human capacity to act ${ }^{59}$ further into the direction of a more pertinent problem. Indeed, with respect to the loss of the relevance of speech and action, a more basic point can be derived if it is kept in mind that Arendt, as early as her dissertation on St. Augustine, premises those capacities on the principle of natality.

Natality purports to express that what makes us human is not the simple fact of being borne a human, as human rights which draw on nativity seem to assume. Rather, what makes us human is the symbolic fact that our birth marks a new beginning in this world. ${ }^{60}$ Our first, biological birth subjects us to the necessities of mere life, but our second birth by which we insert ourselves into the human world through word and deed, makes us free. ${ }^{61}$ Capable to 'act as a beginner' and

57 Ibid.

58 For an extensive discussion on the relation between refugees and democracies, see Ignaas Devisch \& Nanda Oudejans, 'De grenzen van de Gemeenschap: Over immigratie en de hedendaagse democratie,' Res Publica 53 (1) (2011): 65-90.

59 Krause, 'Undocumented Migrants,' 335.

60 Cf. Hannah Arendt, Love and St Augustine (Chicago: Chicago University Press, 1996), 55.

61 Cf. Arendt, The Human Condition, 157. 
'to enact the story of mankind,' 62 humans never simply are but rather 'human existence consists in acting and behaving in some way or other.' ${ }^{63}$ Natality reminds us that 'the human' is a singular existence exposed to plurality, embedded in a meaningful network of relations with things and persons, and delivered over, as Heidegger would say, to its world. As the principle of speech and action, natality is what makes us share a world together with others and what enables us to inhabit a world. To push the point a bit further, natality calls to mind that the human of human rights always exists somewhere in particular.

To exist somewhere in particular reveals the decisive difference between natality and nativity. The latter illuminates the popular concept of 'country of origin.' Nativity indeed has a long-standing tradition in matters of membership and rights-attribution. It roots the human in a territory (ius soli) or fixes him in a bloodline (ius sanguinis). Note, however, that nativity is inconclusive when it comes to legal membership. From the viewpoint of nativity, the injunction that no one be deprived of the right to change his nationality (Art. 15(2) of the Universal Declaration of Human Rights) is incomprehensible. Nor does it explain that in some cases migrants who are declared to be undesirable aliens are protected against expulsion to their country of origin on the understanding that this would destruct their life and identity. As the European Court of Human Rights recently ruled, expulsion to the country of origin would constitute a breach of Article 8 ECHR which 'protects the right to establish and develop relationships with other human beings and the outside world. ${ }^{64}$ When it comes to membership and residence rights, the concept of 'one's own country' is therefore far more significant than 'country of origin.' Indeed, it is striking that the one basic right that is a direct function of nationality, to wit freedom of movement, states the right of everyone to leave any country, including his own, and to return to his country. ${ }^{65}$

The very expression 'one's own country' dovetails 'place' and 'identity,' and manifests the intimate relation between who you are, where you are and how you are together with others. ${ }^{66}$ Nativity which predicates membership and rights on birth and/or origin falls short of this. Natality ${ }^{67}$, by contrast, does not reflect an origin, but a life of speech and action through which we 'take upon ourselves the naked

62 Arendt, Love and St. Augustine, 53.

63 Ibid., 55.

64 A.A.v. The United Kingdom, App. No. 8000/08, ECtHR (2011).

65 See International Covenant on Civil and Political Rights article 12(2) read in conjunction with article 12(4).

66 For a philosophical understanding of the relation between place and identity, see Bernhard Waldenfels, 'Pheneomenology of Space: Being Here and Elsewhere,' in A Right to Inclusion and Exclusion? Normative Fault Lines of the EU's Area of Freedom, Security and Justice, ed. Hans Lindahl (Oxford: Hart Publishing, 2009), 95-114.

67 For an interpretation of the notion of one's own country from the perspective of natality, see also Bert Van Roermund, 'Migrants, Humans and Human Rights: The Right to Move as the Right to Stay,' in A Right to Inclusion and Exclusion? Normative Fault Lines of the EU's Area of Freedom, Security and Justice, ed. Hans Lindahl (Oxford: Hart Publishing, 2009), 161-84. 
fact of our original physical appearance. ${ }^{68}$ And in doing so we share a world together with others of our kind and take up a place of our own.

That the refugee is stripped of public appearance and tormented in his speaking capacity therefore also means that he has lost a place he can call his own. The fundamental deprivation of a place in the world draws attention to what Casey calls the 'terrifying experience' of 'being unplaced,' of having 'no proper or lasting place, no place to be or to remain.' ${ }^{69}$

This sheds new light on Arendt's assertion that refugees are reduced to mere existence, that is to 'all that is mysteriously given to us by birth' and that 'can be adequately dealt with only by the unpredictable hazards of friendship and sympathy. ${ }^{70}$ In virtue of the loss of an own place, this does not imply that refugees are condemned to a private existence that is lived within the four walls of the house. For obviously, the balefulness of the refugee's situation is that he, in-between departure and arrival, is entirely delivered over to the benevolence of those who are near in the absence of a law that protects him. Indeed, reduction to mere existence equally exposes the refugee to hostility, arbitrariness and violence. The dire predicament of the refugee is therefore much more severe than exclusion from the public realm. Wherever he remains he fears the nocturnal knock on the door by the authorities who tell him that he does not belong - not even in his own house - and who are eager to arrest, detain and remove him from the territory. The refugee suffers from a double exclusion: he is excluded from the political life of the citizen and can no longer find shelter in his private existence against this legal and political aberration. ${ }^{71}$

The rupture of the refugee's private life, and of his everyday concerns with the world surrounding him explains the complaint of refugees of all social strata today, namely that they are of no use and rendered entirely superfluous. To be uprooted, Arendt holds, is to lack a place that is guaranteed and recognised by others. And this, she continues, is the preliminary condition for superfluity which means not to belong to the world at all. ${ }^{72}$

\section{Losing One's Abode}

The dreadful experience of not belonging to the world not only reflects a personal problem. As this section argues, it also draws attention to the importance of place in matters of rights, equality and freedom.

71 Cf. also Giorgio Agamben, Homo Sacer. Sovereign Power and Bare Life (Stanford: Stanford University Press, 1998), 187-8.

72 Cf. Arendt, The Origins of Totalitarianism, 475. 


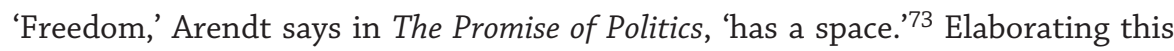
time on the Greek understanding of law as nomos she argues that 'freedom was rooted in place, bound to one spot and limited in its dimensions. ${ }^{74}$ And in her impatience with popular talk about 'world citizenship' and 'universal equality' she points out that the rights of the individual are not only limited by the rights of his fellow citizens, but by the boundaries of a territory as well. ${ }^{75}$ Rights, in short, require the legal emplacement of the individual. ${ }^{76}$ Lindahl captures the point with great clarity when he argues that 'to ascribe rights and obligations is also always to assign a legal place to a person and vice versa. ${ }^{.77}$

The refugee's loss of place is a bleak reminder that rights and freedom are always necessarily spatially limited. Hence the right to have rights reflects that rights do not simply befall the human being but instead require a status that (1) identifies the individual in terms of rights and duties and (2) allocates the individual to a state responsible for granting those rights and duties. For the individual concerned this is not merely a technical or formal matter but carries an existential meaning as well: the place where one enjoys rights and moves about in freedom is not simply a geographical substrate and even less an arbitrary position in space. The place where one is free is first and foremost one's own place.

As long as each individual has a legally sealed place of its own, we live in a common world. 'All laws,' Arendt argues, 'first create a space in which they are valid and this space is the world in which we can move about in freedom. ${ }^{78}$ Indeed, freedom of movement manifests the 'commonness' of the free world. If I cross the borders of the polity in which I hold legal membership, I do not encounter an empty space. Instead, I enter upon the territory of a different state. This shows, as Lindahl argues, that borders not only separate one polity form the other, but also unite what they separate into an encompassing whole. Without uniting what borders separate there would not be a foreign country, but a desert. By the same token, the other would not be a foreign national belonging to another state, but a barbarian. To say that borders unite what they separate is to say that we live in a common world in which each and every individual has a place of its own. ${ }^{79}$

Yet refugees, Arendt notes, 'are forced outside the common world' ${ }^{80}$ and their deceptive freedom of movement 'gives them no right to residence. ${ }^{81}$ That rights, freedom, and equality require spatial limitation, and that this limitation gives the

80 Arendt, The Origins of Totalitarianism, 302.

81 Ibid., 296. 
human a place which he can call his own, reveals in all its vehemence the refugee's plight. Upon escape from the home country, the refugee not only crosses a physical border; he also moves outside the bond of protection that connects him - even if ineffective - to a state. And in so doing he not only forfeits legal protection by the former state but also he loses his own place which is legally warranted. The refugee loses his abode, that is the place where he abides by the law and where he is properly dwelling.

The refugee's deprivation of a place in the world understood in the strong sense of the loss of a legal own place weaves another thread of thought in Arendt's distrust of human rights. What troubled her was not only that human rights collapsed into the rights of citizens and therefore failed to protect refugees; what worried her even more was that the international community, in the build-up to a legal arrangement for refugees, lingered to acknowledge that refugees are no longer citizens, - and invented the category of de facto stateless persons. As will be argued below, de facto statelessness keeps the refugee out of sight as an unplaced person with the effect that "[a]ll discussions about the refugee problem revolved around this one question: How can the refugee be made deportable again?'82 As will become clear, the very concept of de facto statelessness is at the root of the perplexities pertaining to the concept of asylum.

\section{De Facto and De Jure Statelessness}

Recall that Arendt's misgiving with respect to human rights echoed the international community's concern with respect to the protection gap in international law. The refugee's exclusion from international law was highlighted in 1949 by the International Refugee Organization (IRO) in a decisive letter to the Social and Economic Council. 'The refugee,' the IRO stated, 'is an alien in any and every country to which he may go. He does not have the last resort which is always open to the "normal alien" - return to his own country (...) Moreover, the refugee is not only an alien wherever he goes, he is also an "unprotected alien" (...) 83

From the viewpoint of international law, the refugee was not, strictly speaking, an alien, i.e. a foreign national who, on account of his nationality, belonged to another state. If, as the IRO voices, the refugee constituted 'an anomaly in international law's4 this certainly was because he could no longer be properly located in a foreign state where he on account of his nationality supposedly belonged. The refugee was anomos because he had become atopos. Indeed, although refugees often formally retained their nationality, the international community deemed it inappropriate to continue to regard them as nationals of a state that abused its

83 Communication from the International Refugee Organization to the Economic and Social Council (1949) as cited in James Hathaway, The Rights of Refugees under International Law (New York: Cambridge University Press, 2005), 59-60. 
power as a weapon of persecution. ${ }^{85}$ Refugees were, therefore, placed on equal footing with stateless persons destitute of protection due to the absence of nationality. In fact, both refugees and stateless persons were classified under the common denominator of 'unprotected persons.' 86

From a legal point of view it may seem as if Arendt finished The Origins a little bit too early. The adoption in 1951 of the Refugee Convention seemingly takes away Arendt's concerns over the breakdown of human rights since the Convention fills the protection gap in international law by tackling the lack of protection that befalls a person upon fleeing and that he experiences outside his own country. ${ }^{87}$ Therefore, the explicit purpose of the Convention is to restore the legal person of the refugee so as to 'assure refugees the widest possible exercise of [their] fundamental rights and freedoms. ${ }^{88}$ Given this purpose, the Convention imposes upon states the absolute prohibition of refoulement. Also, it affords refugees such basic rights as the right to housing, education, work and the rights to freedom of movement and religion. The conferral of refugee status proves, it could be argued, the reality of human rights beyond the legal bonds of nationality and outside the context of citizenship.

However, it is highly doubtful whether this would have satisfied Arendt. On closer inspection, it appears that she was highly sceptical of the concept of the refugee as developed in the post-war period and that underpinned the legal arrangements that came into existence. Arendt holds the 'core of statelessness' to be 'identical to the refugee problem. ${ }^{89}$ She therefore explicitly targeted the emerging difference between de facto and de jure statelessness which she casts as one of the many efforts to simplify the refugee problem ${ }^{90}$ with the 'express purpose of liquidating statelessness once and for all by ignoring its existence. ${ }^{91}$ According to Arendt, de facto statelessness is nothing but the refusal to recognize the refugee as a stateless person 'thereby making the situation of refugees even more intolerable.' 92

Indeed, as to the conceptual understanding of the refugee problem, a decisive division was made within the group of unprotected persons, separating refugees from stateless persons. Although it proved to be a difficult task to draw the line, ${ }^{93}$

85 Cf. Paul Weis, Nationality and Statelessness in International Law (Alphen a/d Rijn: Sijthoff \& Noordhoff International Publishers, 1979), 59-60.

86 Ibid., 44.

87 Cf. James Hathaway, The Law of Refugee Status (Toronto: Butterworths, 1999), 4.

88 Consideration 2 of the Preamble to the 1951 Convention Relating to the Status of Refugees.

89 Arendt, The Origins of Totalitarianism, 279.

90 Ibid., 281, supra note 28.

91 Ibid., 279.

92 Ibid., 281.

93 For the perplexities that emerged when stating the difference between refugees and stateless persons, see Nehemiah Robinsion's influential interpretation of the drafting history of the 1954 Stateless Convention: Nehemiah Robinson, Convention Relating to the Status of Stateless Persons. Its History and Interpretation, Published by the World Jewish Congress 1955, reprinted by UNHCR in 1997, available at: www.unhcr.org. 
the distinction - formally sealed by different Conventions ${ }^{94}$ - was made mainly because of the perceived difference in the root causes of the respective phenomena. As statelessness is the reverse of nationality, its causes were believed to be rather technical and legal in nature, resulting from gaps and obstacles in nationality legislation. Clearly, statelessness can only be definitely resolved by the attribution of nationality. As UNHCR recently explained, recognition of statelessness 'can be a stepping-stone to the acquisition of nationality.'

Refugeeship, by contrast, is a political, rather than a legal problem as it is the effect of a perverted relation between the individual and the state authorities. Grahl-Madsen cast the refugee's lack of protection as the symptom of which persecution is the disease. ${ }^{96}$ Refugees, he argued, 'are unprotected as a matter of fact, not as a matter of law, as are the stateless. ${ }^{\text {'97 }}$

These are the magic words that motivated the distinction between de facto statelessness and de jure statelessness. The former purports to express that the refugee's lack of protection is a brute but not a legal fact, whereas de jure statelessness reflects a formal lack of protection as there is no single state on earth that can be attributed legal responsibility for the individual concerned. Qualifying the refugee's lack of protection as a brute fact, de facto statelessness reflects the assumption that the refugee is in principle a national (or resident) of the country of origin.

Van Waas, a prominent legal scholar on statelessness, makes the assumption explicit. Commenting on the aforementioned letter from the IRO which, recall, drew attention to the refugee as an 'unprotected alien', she argues:

'This dire predicament indeed befalls the refugee, since the factual situation in the country of origin prevents him from returning home to exercise his rights as a national or calling in the assistance of his home country. However, where the stateless are concerned, this fate is sealed in legal terms - only to be resolved through the attribution or restoration of the bond of nationality. 98

On the understanding that only factual circumstances prevent the refugee's return 'home,' the lack of a legal own place is altogether removed from the refugee problem. Indeed, on a widely received view the desperate experience to belong nowhere in this world is kept in reserve for the stateless. As Van Waas argues: ' $[\mathrm{N}]$ o nationality, so no automatic right to (re)enter or reside anywhere.' And this

In 1954 the Convention Relating to the Status of Stateless persons was adopted, followed by the adoption in 1961 of the Convention on the Reduction of Statelessness.

95 Cf. UNHCR, 'Action to Address Statelessness: A Strategy Note,' International Journal of Refugee Law 22 (2010): 313.

96 Grahl-Madsen, The Status of Refugees in International Law (Leiden: Sijthoff, 1966), 98-9.

97 Cf. ibid., 97.

98 Laura van Waas, Nationality Matters. Statelessness under International Law (Antwerpen: Intersentia, 2008), 225. 
fact, she goes on to explain, reveals the fundamental dilemma for the stateless: 'where do they have a right to live?'99

On account of the notion of de facto statelessness the answer to the same question is relatively simple for refugees. As their distress is a matter of fact, not a matter of law, they have a right to live in their own country. Van Waas is ready to admit that this is virtually impracticable for refugees. Yet she nevertheless holds that 'their position can be resolved by return to the country of nationality.' 100 Driven to the limit, de facto statelessness assumes that refugees, at the end of the day, ought to be 'there,' in their country of origin, not 'here,' in the country of asylum where they are non-nationals and hence do not belong. It was for exactly this reason that the International Law Commission's Special Rapporteur Cordova exposed de facto statelessness to be detrimental to refugees. In his 1951 report on statelessness Cordova unavailingly pleaded to reconsider the refugee problem, arguing that

'These de facto stateless persons have sought refuge in foreign countries and have established there a residence which they perhaps intended to be temporary (...) but which may have become, in fact, permanent or, at best, indefinite. The recipient countries have accepted them for humanitarian reasons and (...) have resigned themselves to allowing them to stay, postponing sine die the final settlement of the problem but always maintaining the threat of some drastic action concerning them.' ${ }^{101}$

Arendt, no doubt, would have agreed with Cordova as de facto statelessness breathes life in the stubborn view that refugees, as Harell-Bond and Verdirame put it, "have an eternal and visceral tie with the country of origin - "home" - the place to which they always belong. ${ }^{\text {'102 }}$ As Arendt herself notes, 'non-recognition of statelessness always means repatriation.' ${ }^{103}$ Indeed, it is no coincidence that States, ever since the adoption of the Refugee Convention in 1951, have favoured 'return home' as the durable solution for the refugee problem over against the integration of refugees in countries of asylum. If, today, Western States are reluctant to open their borders for Syrian refugees and grant them asylum within their own communities, the reluctance is justified by the claim that eventual return home of the refugees to Syria is the preferred solution which is facilitated if they are given shelter 'there,' that is in the region of origin, and not 'here.'

But the snag is of course, as Arendt very well knew, that all too often 'home' no longer exists. 'There' where the refugee supposedly belongs is no longer a quali-

99 Ibid., 246.

100 Ibid., 223 supra note 35.

101 As cited in Hugh Massey, 'Legal and Protection Policy. UNHCR and de facto Statelessness,' Research paper UNHCR (2010), available at www.unhcr.org: 14.

102 Barbara Harell-Bond \& Guglielmo Verdirame, Rights in Exile. Janus Faced Humanitarianism (New York: Berghahn Books, 2005), 335.

103 Arendt, Origins of Totalitarianism, 279. 
fied and determined somewhere - a foreign country, a different state - where the refugee by virtue of his legal attachments ought to be. To the contrary, and quite literally, 'there' where the refugee supposedly belongs loses its determinacy and becomes a 'no matter where as long as it is not here.' It becomes a 'safe country of origin,' a 'safe third country,' a 'country of safe first arrival,' a territory where regional protection is offered, or indeed a refugee camp - which are all legal definitions deployed by creative asylum policies that seek to keep refugees at bay. Those policies are the upbeat to further explorations of extra-territorial asylum policies in the future that seek to disconnect refugee protection from their immigration to Western countries (captured by Tony Blair's infamous slogan 'pro refugee anti-asylum'), and that have spurred the European Commission in the past to sign a cooperation agreement, including a 50 million euro for border control, with Mu'ammar al-Gaddafi, ${ }^{104}$ who depicted the refugee problem as 'a widespread lie' and thought that it was 'really a laughable matter.' 105

It has often been noticed that somewhere between the lofty humanitarian ideal to 'assure refugees the widest possible exercise of [their] fundamental rights and freedoms ${ }^{106}$ and the actual practice of asylum, the system of refugee protection is falling apart. ${ }^{107}$ At the close of the twentieth century James Hathaway diagnosed 'the decimation of the practical value of formal refugee law by policies of nonentrée, and the containment of refugees in their country of origin. ${ }^{108}$ Of course, states did factor in the negative when it comes to refugee protection. But it is no less true that the concept of de facto statelessness was never well-equipped to serve the lofty humanitarian ideal of assuring refugees the widest possible exercise of their rights and freedoms. De facto statelessness covers up the refugee's loss of an own place, veils his displacement. Indeed, if, as common usage has it, refugees are said to be displaced persons, their displacement should be taken in the strong sense in which Lindahl understands it; as the lack of an own legally warranted place within the common world. ${ }^{109}$ The specific contribution of The Origins is to have revealed the refugee's deprivation of place in this world in virtue of which it is reductive to stage an opposition between the refugee's lack of protection as a brute fact and the stateless person's lack of protection as a legal fact. The refugee is as well, to borrow from the French, apatride, without a father-

104 Cf. Human Rights Watch, World Report 2011, 423.

105 Mu'ammar al-Gaddafi as cited in: Human Rights Watch, Pushed Back, Pushed Around. Italy's forced Return of Boat Migrants and Asylum Seekers, Libya's Mistreatment of Migrants and Asylum Seekers (2009), 10.

106 Consideration 2 of the preamble to the Convention relating to the Status of Refugees of 28 July 1951.

107 According to Harell-Bond and Verdirame refugees are the 'worst-treated' aliens in many countries. See Harell-Bond \& Verdirame, Rights in Exile, 341.

108 J. Hathaway, 'Preface: Can International Refugee Law be Made Relevant Again?,' in Reconceiving International Refugee Law, ed. J. Hathaway (The Hague: Nijhoff, 1997), xxiv.

109 Compare Lindahl, 'Give and Take,' 888-9: '[I]individuals who are not in-legal-place (...) are not simply misplaced in virtue of not being where they ought to be; instead they are displaced, that is to say, they claim a legal place of their own for which there is no place within the distribution of places made available by a region.' 
land. Through the looking glass of the right to have rights both the refugee and the stateless persons lack a place of their own and face the dilemma: where do they have a right to live? This dilemma, as will be argued below, illuminates the refugee's claim to asylum.

\section{Asylum. Or Claiming a Place of One's Own}

Over the course of past decades refugee protection increasingly came to be limited to protection against refoulement, without due respect being paid to other fundamental rights which the 1951 Convention affords refugees. ${ }^{110}$ Sure, protection against refoulement is certainly the first exigency to be met and can even be considered to be the corner stone of the international refugee protection regime. ${ }^{111}$ But the point of the matter is that protection, and even more narrowly protection against refoulement, safeguards the naked life of the refugee at the price of separating his or her life from its human possibilities. Indeed, detaching protection from any positive aspect thereof irredeemably undresses it, ${ }^{112}$ and effectively disempowers refugees to build their lives anew, turning countries of asylum into waiting rooms where their lives are suspended until such time as they can return to wherever it is they once came from. Goodwin-Gill and McAdam put the undressing of protection to the spot when they argue that 'non-refoulement has separated itself from asylum in the sense of a lasting solution. ${ }^{113}$ In this respect it is worth mentioning that, as Kimminich shows in Asylrecht (1968), 'asylum' has a double meaning referring both to 'protection' and the 'place' where protection is offered. ${ }^{114}$ Yet Kimminich also shows that the international community in the twentieth century resolutely limited asylum to protection with the effect that the importance of place disappeared from consciousness altogether. ${ }^{115}$

Arendt's analysis urges us to take the notion of place back into the account of asylum. Against the backdrop of the loss of an own place, the refugee not only claims protection as is commonly assumed. Also, he claims a place of his own where protection can be enjoyed again. Indeed, the Refugee Convention's ambition to assure refugees the widest possible exercise of their rights and freedoms is contingent upon the very thing that was cut out of the understanding of asylum: place. Protection in the full meaning of the 1951 Refugee Convention requires the

110 Cf. Hathaway, The Rights of Refugees under International Law, 2-3.

111 In its Introductory Note to the Refugee Convention from 2006, UNHCR stipulates: 'Certain provisions of the Convention are considered so fundamental that no reservations may be made to them. These include the definition of the term "refugee," and the so-called principle of nonrefoulement, i.e., that no contracting State shall expel or return ("refouler") a refugee, against his or her will, in any manner whatsoever, to a territory where he or she fears persecution.'

112 Durieux also critically argues that the 'refugee definition is not intended to describe those whom we cannot deport, but, positively, those aliens whom we want to protect' (J. Durieux, 'Salah Sheekh is a Refugee. New Insights into Primary and Subsidiary Forms of Protection,' Refugee Studies Centre Working Paper no. 49 (October 2008), 17).

113 Goodwin-Gill and McAdam, The Refugee in International Law, 344.

114 Cf. Otto Kimminich, Asylrecht (Berlin: Luchterhand, 1968), 7.

115 Cf. ibid., 33. 
legal emplacement - instead of seclusion - of refugees within host societies. The Refugee Convention is indeed like a wall. However, not a wall behind which refugees can shelter, - which was the slogan adopted by UNHCR to celebrate the Convention's $50^{\text {th }}$ anniversary ${ }^{116}$; but rather a wall that, like the walls of the citystate, hedges in freedom and gives place to refugees. By reintroducing the notion of place, asylum appears as the anticipated possibility of becoming rooted again, while not precluding the possibility that people upon their own decision might wish to return. Illuminating the refugee's claim to asylum as a claim to a legal own place, Hannah Arendt's right to have rights beckons governments to develop and embrace asylum policies that better serve the aim of the 1951 Refugee Convention and to strike a fair balance between 'return home' and 'local integration' as the two durable solutions to the refugee problem. Moreover, it warrants the repeated recommendations of the Council of Europe to treat de facto stateless refugees as if they are de jure stateless as this would enable, indeed, their integration in countries of asylum and hence contributes to a durable solution to the refugee problem. ${ }^{117}$

116 Cf., UNHCR, Refugees. 50th Anniversary. The Wall Behind which Refugees can Shelter. The 1951 Geneva Convention 2 (123) (2001). Available at www.unhcr.org.

117 Cf. Council of Europe Recommendation 564 (1969); Council of Europe Recommendation 696 (1973). 